\title{
Removal of Copper Using Clay Admixed with Quarry Fines as Landfill Liners
}

\author{
Rajagopalan Varadarajan ${ }^{1 *}$, G.Venkatesan², \\ G. Swaminathan ${ }^{3}$ \\ ${ }^{1}$ Research Scholar, Department of Civil Engineering, University College of Engineering (BIT Campus), \\ Anna University, Tiruchirappalli, India \\ ${ }^{2}$ Department of Civil Engineering, University College of Engineering, (BIT Campus), \\ Anna University, Tiruchirappalli, India \\ ${ }^{3}$ Department of Civil Engineering, National Institute of Technology, \\ Tiruchirappalli, India
}

Received: 5 July 2015

Accepted: 22 September 2015

\begin{abstract}
The liners in a sanitary landfill play a significant role in reducing the leachate migration and minimizing groundwater pollution. This research investigated a method for the removal of copper ions from aqueous solutions using natural clay admixed with quarry fines as a liner material in landfills. Batch experiments were carried out under different conditions such as $\mathrm{pH}$, contact time, adsorbent dose, and metal concentration. The results showed that the metal ions uptake by clay (admixed with quarry fines) was rapid at from 3 to 15 minutes, after which adsorption of metal ions remains constant. The equilibrium was achieved practically in $15 \mathrm{~min}$ with a removal percentage of copper equal to $94.5 \%$. The removal of copper increased when the $\mathrm{pH}$ increased from 2 to 5.6. At $\mathrm{pH}$ values higher than 5.6, a reduction in the removal efficiency was observed. The experimental results were mathematically modeled according to the two known adsorption models of Langmuir and Freundlich and the data better fit the Freundlich isotherm model. Thus, clay admixed with quarry fines used in this work, as adsorbent for Copper removal, revealed great retention capacity, making it very suitable for use as clay barriers in public landfills.
\end{abstract}

Keywords: adsorption, clay liner, quarry fines, copper, isotherm

\section{Introduction}

Industries situated in urban areas choose to dispose of their solid waste in a favorable site where municipal solid waste is disposed of. The heavy metals contained therein were unaffected during degradation of organic waste, and as such, when it accumulated beyond the allowable

*e-mail: vrgopalanaut@gmail.com concentration limit, the heavy metals produce toxicity that affects living organisms and causes environmental problems. The proper treatment and safe disposal of the leachate is a major concern throughout the world [1]. Therefore, the issue of heavy metals is a topic of concern along with the design of a liner system in waste disposal landfills. The studies done in the past reveal that the concentrations of arsenic, mercury, chromium, cadmium, lead, nickel, and zinc (As, $\mathrm{Hg}, \mathrm{Cr}, \mathrm{Cd}, \mathrm{Cu}$, $\mathrm{Pb}$, Ni and $\mathrm{Zn}$ ) were estimated and found to be in $\mathrm{mg} / \mathrm{kg}$ 
levels in municipal solid waste and in $\mu \mathrm{g} / \mathrm{L}$ in leachates and water extracts. The status of heavy metals distribution in municipal solid waste disclosed that the concentration of $\mathrm{Cr}$ was comparatively less than that of other metals $(\mathrm{Cu}$ and $\mathrm{Pb})$. In certain cases, metal contents were beyond the limits, as prescribed for compost by the Central Pollution Control Board (CPCB) [2].

Compacted natural clay soil was used for liners and covers in waste containment facilities. Clay was preferred as an abundant and a low-cost material, and more importantly it has the highest attenuation factor and adsorption capacity for ion exchange sites. The primary function of a landfill liner system is to protect groundwater due to the impact of leachate [3,4]. Soil liners were reported and used for many years and served as an engineered hydraulic barrier for solid waste contaminant facilities $[5,6]$. On the other hand, quarry fines are the waste material with inherent fraction of an aggregate passing through a $0.063 \mathrm{~mm}$ sieve. Quarry waste consists mainly of excess fines generated from crushing, washing, and screening operations at quarries. Waste from quarry and fabrication operations could be unsafe and environmentally detrimental. Bulk utilization of this quarry waste material is possible through geotechnical applications like embankments, back-fill material, and sub-base material. It would be a useful additive to the natural soil to improve the strength characteristics of the soil. The adsorption receives considerable interest with high efficiency for removal of heavy metal than other methods like ion exchange, chemical settling, and reverse osmosis [7].

The adsorption of heavy metal ions on clay has been comprehensively studied [8-10]. Kaolinite, montmorillonite, and their poly and tetra butyl ammonium derivatives were used for removing Cd (II) from aqueous solution [11]. The removal of metal ions from aqueous solutions by adsorption has been reported by various studies: $\mathrm{Pb}(\mathrm{II}), \mathrm{Zn}(\mathrm{II}), \mathrm{Cd}(\mathrm{II})$, and $\mathrm{Cu}(\mathrm{II})$ onto natural clay [12]; radio nuclides (137Cs) on kaolinite [13]; $\mathrm{Pb}$ (II), $\mathrm{Cu}(\mathrm{II}), \mathrm{Fe}(\mathrm{III}), \mathrm{Mn}(\mathrm{II})$, and $\mathrm{Zn}$ (II) onto kaolinite clay [14]; $\mathrm{Cd}(\mathrm{II}), \mathrm{Cu}(\mathrm{II}), \mathrm{Pb}(\mathrm{II})$, and $\mathrm{Zn}$ (II) onto waste calcite sludge [15]; $\mathrm{Zn}(\mathrm{II}), \mathrm{Cd}(\mathrm{II}), \mathrm{Pb}(\mathrm{II})$, and $\mathrm{Cu}(\mathrm{II})$ onto natural Jordanian zeolite[16]; $\mathrm{Pb}(\mathrm{II}), \mathrm{Cu}(\mathrm{II}), \mathrm{Cd}(\mathrm{II})$, and $\mathrm{Ni}(\mathrm{II})$ onto Iranian natural zeolite [17]; $\mathrm{Pb}$ (II) and $\mathrm{Cd}(\mathrm{II})$ onto clay mineral beidellite [18]; and Zinc(II) onto modified Brazilian gray clay [19].

This study was aimed at investigating the removal of copper ions from aqueous solution. The effects of $\mathrm{pH}$, clay admixture amount, metal concentration, and contact time on copper removal by the liner material comprising natural clay admixed with quarry fines was studied.

\section{Materials and Methods}

\section{Standard Solution}

Stock standard solution of $\mathrm{Cu}(\mathrm{II})$ was prepared by dissolving the appropriate amount of $\mathrm{CuSO}_{4} \cdot 5 \mathrm{H}_{2} \mathrm{O}$ in double-distilled water. This stock solution was then diluted to the required concentrations by varying $\mathrm{pH}$ using $0.1 \mathrm{~N}$ hydrochloric acid $(\mathrm{HCl})$ and $0.1 \mathrm{~N}$ sodium hydroxide $(\mathrm{NaOH})$. All chemicals used were of analytical grade and supplied from Madras Scientific Company.

\section{Adsorbent}

The natural clay used for the study was collected from a natural deposit in Lalkudi-Trichy, Tamilnadu (India). The quarry fines were obtained from the SRC Projects quarry site in Salem. The samples were dried in an oven at approximately $105^{\circ} \mathrm{C}$ and used in their natural state with no chemical modifications. Clay $(\mathrm{C})$ and quarry fines $(\mathrm{QF})$ were blended to prepare composite liner. The proportion of quarry fines used in the mixture was $0 \%, 5 \%, 10 \%$, $15 \%, 20 \%$, and $25 \%$ of the total weight of composite sample labelled as CQF1, CQF2, CQF3, CQF4, CQF5, and CQF6, respectively.

\section{Instrumentation}

The adsorption experiments were studied by batch technique using a Remi orbital shaker. An Elico model SL-243 atomic absorption spectrophometer was used for determining concentration of metal ions. The following conditions are used for testing of $\mathrm{Cu}$ : wave length $324.7 \mathrm{~nm}$, slit width $0.125 \mathrm{~nm}$, lamp current $7.7 \mathrm{ma}$, and an air-acetylene burner. The flow rate of acetylene and air was adjusted as per manufacturer guidelines. A Remi R-4C model digital centrifuge was used to centrifuge the samples. X-ray diffraction was used to determine basic mineralogical composition of the natural clay. XRD patterns of clay were obtained on a Bruker AXS D8 Advance with $\mathrm{CuK} \alpha$ radiation X-ray powder diffractometer. To identify the involvement of binding groups present on the adsorbent surface, Fourier transform infrared spectroscopy (FTIR) images were recorded on PerkinElmer FTIR Spectrum BXI using the KBr pellets method, and spectra were recorded in the range of $400-4,000 \mathrm{~cm}^{-1}$.

\section{Adsorption Procedure}

The laboratory-scale adsorption experiment was carried out using $100 \mathrm{ml}$ of $\mathrm{Cu}$ metal ion solution of desired concentration $(20 \mathrm{mg} / \mathrm{L})$. Six batch adsorption test in series were performed to determine the adsorption behavior of the clay and quarry fines for copper removal. In the first series, the clay was used without admixtures. In successive series, the same set of experiments was carried out for the clay with quarry fines mixed in different proportions as discussed earlier. For each of the individual adsorbents during the experiment the following variations and inferences were made: adsorbent treatment time, adsorbent dose, $\mathrm{pH}$ of the solution, and initial concentration. The effect of contact time on the adsorption capacity of the adsorbents with copper solution was investigated in the range of 3-120 min for an initial 
concentration of $20 \mathrm{mg} / \mathrm{L}$. For the given concentration of $20 \mathrm{mg} / \mathrm{L}$, the dose of adsorbents varied from 0.1 to $1 \mathrm{~g}$ and the effects of $\mathrm{pH}$ from 2 to 8 also were studied.

The sample was withdrawn from the shaker at predetermined time intervals and filtered through the centrifuge apparatus, which runs at 3,000 rpm, for 5 minutes. The concentration of copper left out in the solution was analyzed by atomic absorption spectrophotometry. Langmuir isotherm and Freundlich isotherm constants were found for clay liner composites.

The percent adsorption of metal ions was calculated as follows:

$$
\text { Sorption } \%=\left(\frac{\mathrm{Ci}-\mathrm{Ce}}{\mathrm{Ci}}\right) \times 100
$$

The sorption capacity at time $t, \mathrm{q}_{\mathrm{e}}(\mathrm{mg} / \mathrm{g})$ was obtained by Eq.(2):

$$
\mathrm{q}_{\mathrm{e}}=\left(\frac{(\mathrm{Ci}-\mathrm{Ce}) \mathrm{V}}{\mathrm{m}}\right)
$$

... where $C i$ and $C e(\mathrm{mg} / \mathrm{L})$ were the initial and equilibrium concentrations of $\mathrm{Cu}(\mathrm{II}), V$ was the solution volume (L), and $\mathrm{m}$ the mass of adsorbent $(\mathrm{g})$.

\section{Results and Discussion}

\section{XRD Characterization}

The X-ray powder diffraction (XRD) analysis was performed on bulk sample to identify the major clay and non-clay minerals present. The existence of minerals in natural clay was identified by comparing ' $d$ ' values (Selected Powder Diffraction Data for Minerals, 1974; Powder Diffraction File Search Manual Minerals, 1974) [20]. Fig. 1 shows the X-ray diffraction pattern of the bulk sample. The main clay minerals present are

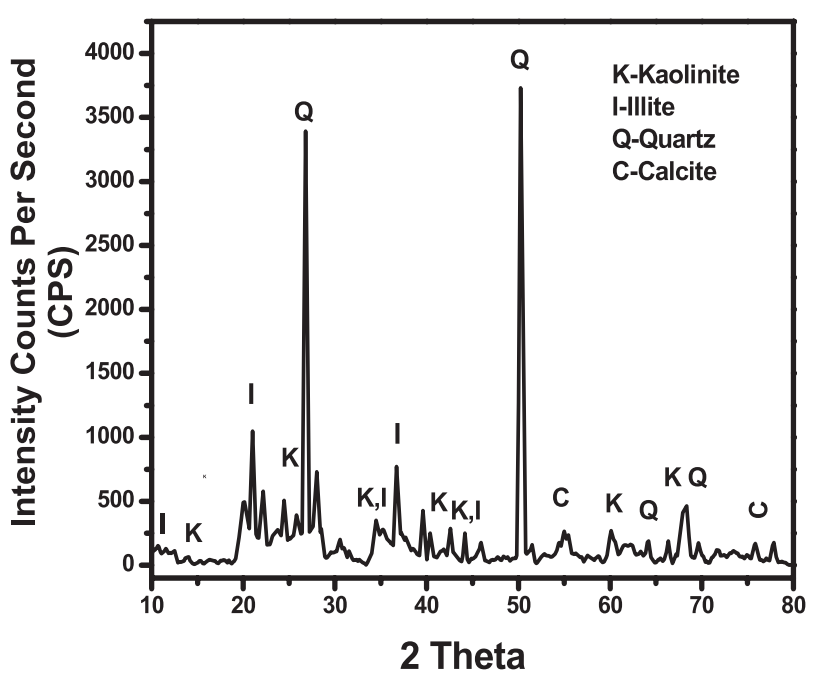

Fig. 1. XRD diffractogram of the bulk sample clay. kaolinite $\mathrm{Al}_{2} \mathrm{Si}_{2} \mathrm{O}_{5}(\mathrm{OH})_{4}$ (card No. 5-0143) and illite $\mathrm{KAl}_{2} \mathrm{Si}_{3} \mathrm{AlO}_{10}(\mathrm{OH})_{2}$ (card No. 2-0056) in lower proportion. The sample contains quartz $\mathrm{SiO}_{2}$ (card No. 81-0069) and calcite $\mathrm{CaCO}_{3}$ (card No. 3-0593) as secondary phases.

\section{Fourier-transform Infrared Spectroscopy (FTIR)}

Comparisons were made using the FTIR spectra of CQF5 before and after $\mathrm{Cu}$ (II) adsorption to observe the surface functional groups occupied in the binding of $\mathrm{Cu}$ (II) ions as shown in Figs 2 a, b and Table 1.The triclinic layer structure of pure Kaolinite exposes four well-resolved $(-\mathrm{OH})$ bands in the IR spectrum. Three of these bands were assigned to the stretching vibrations of surface hydroxyl groups $\left(3694 \mathrm{~cm}^{-1}\right)$ while the fourth $\left(3620 \mathrm{~cm}^{-1}\right)$ was attributed to the vibrations of inner hydroxyl groups [21, $22]$. The structural $\mathrm{OH}$ bending modes exist in the regions $3,800-3,400 \mathrm{~cm}^{-1}$ and $1,300-400 \mathrm{~cm}^{-1}$, respectively [23]. The FTIR spectrum peaks at $3,694.56-3,435.73 \mathrm{~cm}^{-1}$ in all the spectra ranges was assigned to $\mathrm{OH}$ stretching of inner surface hydroxyl groups $\left(3,694.56 \mathrm{~cm}^{-1}\right), \mathrm{OH}$ stretching of inner hydroxyl groups $\left(3,620.31 \mathrm{~cm}^{-1}\right)$, and $\mathrm{OH}$ stretching of water $\left(3,435.73 \mathrm{~cm}^{-1}\right)$. The spectra ranges $1,651.06 \mathrm{~cm}^{-1}$ and $1,618.47 \mathrm{~cm}^{-1}$ indicates the $\mathrm{OH}$ deformation of water [24]. The Si-O stretching of spectra peaks $1,044.03 \mathrm{~cm}^{-1}, 790.30 \mathrm{~cm}^{-1}, 692.39 \mathrm{~cm}^{-1}$, $540.53 \mathrm{~cm}^{-1}, 476.32 \mathrm{~cm}^{-1}$, and $424.43 \mathrm{~cm}^{-1}$ describes the inplane $\mathrm{Si}-\mathrm{O}$ stretching, $\mathrm{Si}-\mathrm{O}, \mathrm{Si}-\mathrm{O}$ perpendicular, $\mathrm{Al}-\mathrm{O}-\mathrm{Si}$ deformation, Si-O-Si deformation, and Si-O deformation are respective as suggested [25]. The emerging $\mathrm{Si}-\mathrm{O}-\mathrm{Si}$ and Si-O bands also support the presence of quartz [26]. The presence of bands at $3,694.56 \mathrm{~cm}^{-1}, 3,623.23 \mathrm{~cm}^{-1}$, $3,435.73 \mathrm{~cm}^{-1}, 2,359.78 \mathrm{~cm}^{-1}, 1,651 \cdot 06 \mathrm{~cm}^{-1}, 1,044 \cdot 03 \mathrm{~cm}^{-1}$, and $790 \cdot 3 \mathrm{~cm}^{-1}$ designate the possibility of the presence of illite [27].

In CQF5 after $\mathrm{Cu}(\mathrm{II})$ adsorption the $\mathrm{OH}$ stretching of inner hydroxyl groups $3,620.30 \mathrm{~cm}^{-1}$ was shifted as $3,623.23 \mathrm{~cm}^{-1}$, indicating the interactions of CQF5

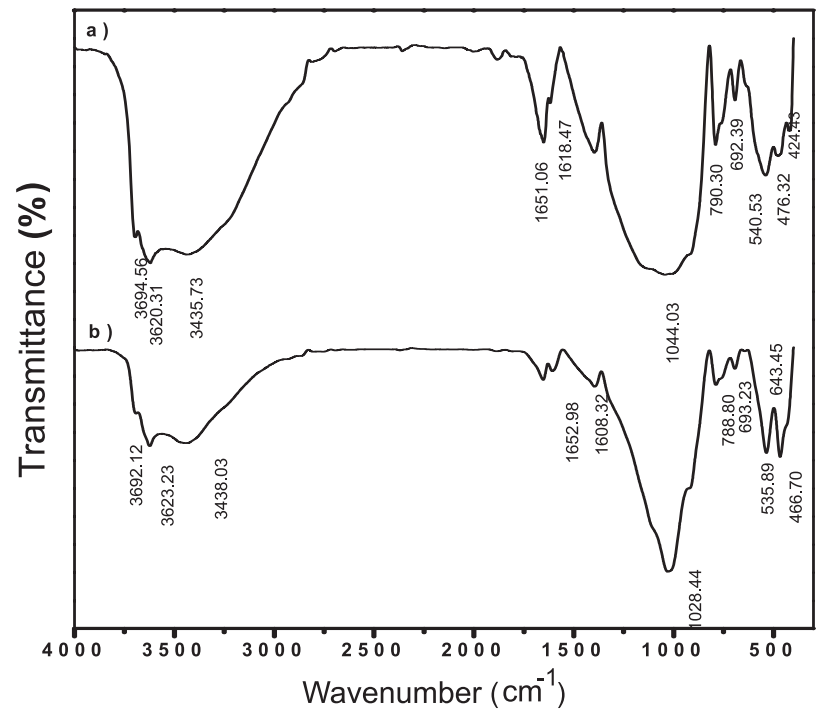

Fig. 2. FTIR spectrum of CQF5 (a) before and (b) after copper adsorption. 
Table 1. FTIR bands of CQF5 before and after $\mathrm{Cu}(\mathrm{II})$ adsorption with possible assignments.

\begin{tabular}{|c|c|c|}
\hline $\begin{array}{c}\text { Functional } \\
\text { groups }\end{array}$ & $\begin{array}{c}\text { CQF5 } \\
\text { Before } \\
\text { Cu(II) } \\
\text { loaded }\end{array}$ & $\begin{array}{c}\text { CQF5 } \\
\text { After Cu(II) } \\
\text { loaded }\end{array}$ \\
\hline $\begin{array}{c}\text { OH stretching of inner- } \\
\text { surface hydroxyl groups }\end{array}$ & 3694.56 & 3692.12 \\
\hline $\begin{array}{c}\text { OH stretching of inner } \\
\text { hydroxyl groups }\end{array}$ & 3620.31 & 3623.23 \\
\hline OH stretching of water & 3435.73 & 3438.03 \\
\hline OH deformation of water & 1651.06 & 1652.98 \\
\hline OH deformation of water & 1618.47 & 1608.32 \\
\hline In-plane Si-O stretching & 1044.03 & 1028.44 \\
\hline Si-O & 790.30 & 788.80 \\
\hline Si-O perpendicular & 692.39 & 693.23 \\
\hline Si-O quartz & - & 643.45 \\
\hline Al-O-Si deformation & 540.53 & 535.89 \\
\hline Si-O-Si deformation & 476.32 & 466.70 \\
\hline Si-O deformation & 424.43 & - \\
\hline
\end{tabular}

adsorbent with $\mathrm{Cu}$ (II) solutions. Further evidence of $\mathrm{Cu}$ (II) adsorption of CQF5 was shifted to the $\mathrm{OH}$ deformation of water and peaks from 1,651.06 $\mathrm{cm}^{-1}$ and 1,618.47 $\mathrm{cm}^{-1}$ to $1,652.98 \mathrm{~cm}^{-1}$ and $1,608.32 \mathrm{~cm}^{-1}$, respectively, at the same time before $\mathrm{Cu}$ (II) adsorption of CQF5 both peaks are narrow and the after $\mathrm{Cu}$ (II) adsorption of CQF5 peaks were narrow and broader [9]. The Si-O stretching of spectra peaks in $\mathrm{Cu}$ (II) adsorption of CQF5 was shifted in inplane Si-O stretching at $1,044.03 \mathrm{~cm}^{-1}$ to $1,028.44 \mathrm{~cm}^{-1}$, and the Si-O stretching bonded band shifted by $15.58 \mathrm{~cm}^{-1}$, indicating the presence of $\mathrm{Cu} \mathrm{SO}_{4}$ with CQF5. Similarly, the Si-O and Si-O perpendicular bonded bands got shifted from $790.30 \mathrm{~cm}^{-1}$ to 788.80 $\mathrm{cm}^{-1}$ and from $692.39 \mathrm{~cm}^{-1}$ to $693.23 \mathrm{~cm}^{-1}$ as very few peak variations, and the vibrations observed at $692.39 \mathrm{~cm}^{-}$ ${ }^{1}$ and $693.23 \mathrm{~cm}^{-1}$ shows the possibility of the presence of calcite [28]. Si-O stretching bands also were observed at $643.45 \mathrm{~cm}^{-1}$, which was presented in Si-O quartz [29] after $\mathrm{Cu}(\mathrm{II})$ adsorption of CQF5. Considering Al-O-Si deformation and Si-O-Si deformation, the peaks shifted at $540.53 \mathrm{~cm}^{-1}$ and from $476.32 \mathrm{~cm}^{-1}$ to $535.89 \mathrm{~cm}^{-1}$ and $466.70 \mathrm{~cm}^{-1}$ based on the interactions of $\mathrm{Cu}$ (II) adsorption with CQF5.

\section{Effects of $\mathrm{pH}$}

It has been reported that the removal of heavy metals by adsorption was dependent on $\mathrm{pH}$ values [30]. $\mathrm{pH}$ is one of the most important monitoring parameters in the process of adsorption. Thus, the effect of $\mathrm{pH}$ on copper adsorption by clay admixed with quarry fines was studied by varying solution $\mathrm{pH}$ from $2-8$ at the constant adsorbent dose of $1 \mathrm{~g} / 100 \mathrm{ml}$ using an initial concentration of $\mathrm{Cu}$ (II) as $20 \mathrm{mg} / \mathrm{L}$. Fig. 3 (a) shows the effect of $\mathrm{pH}$ on adsorption of $\mathrm{Cu}$ (II) onto clay and clay admixture with quarry fines. Adsorption capacity increased when initial $\mathrm{pH}$ of the solution was increased from 2 to 5.6 and adsorption performance decreased from 5.6 to 8. Clay and clay admixture with quarry fine adsorbents shows an increasing trend of the removal process of copper, if the acidity of environment decreases. The optimum $\mathrm{pH}$ was chosen as 5.6 because the precipitation of metal hydroxide was observed at $\mathrm{pH}$ greater than 5.6. Fig. 3 (a) confirms that the optimum $\mathrm{pH}$ for removal of copper from aqueous solution using clay and clay admixture with quarry fines is 5.6.The presence of high numbers of $\mathrm{H}^{+}$ions generate a competition with copper ions for the clay surface sites, which were negatively charged. However, at high $\mathrm{pH}$ values, the concentration of $\mathrm{H}^{+}$ions diminishes and copper was under a hydroxide form $\mathrm{CuOH}^{+}$[3]. At low $\mathrm{pH}$ values adsorption was low where surfaces have a strong positive charge similar to that of the ions. Still, adsorption takes place at low $\mathrm{pH}$ values [31]. In highly alkaline environments heavy metal ions could be transformed to hydroxides that were hardly soluble and precipitate as well. At $\mathrm{pH}$ values higher than 6 the formation of copper hydroxyl compounds affects the sorption process [32].

\section{Effect of Dose}

Adsorbent dosage was an important parameter to determine the capacity of an adsorbent for a given initial adsorbate concentration [33]. In dose analysis, the clay with quarry fines mass fraction varied from 0.1 to $1 \mathrm{~g}$ in order to determine the maximum removal of copper ions while the copper ion solution concentration $(20 \mathrm{mg} / \mathrm{L})$ and its volume $(100 \mathrm{ml})$ were kept constant. The results are shown in Fig. 3 (b). In the removal of copper, it was observed that the adsorption efficiency increased as the clay amount increased. Increasing solid-to-liquid ratio for clay and clay with quarry fines admixture increases the number of active sites available for absorption [31, 33]. As seen in Fig. 3 (b), the optimum dose that can be used in copper removal is $0.8 \mathrm{~g} / 100 \mathrm{~mL}$ and the $\mathrm{Cu}(\mathrm{II})$ removal percentage was found to be $36.01 \%$ at clay dosage CQF1 of $0.1 \mathrm{~g} / \mathrm{L}$, while it reached up to $90.46 \%$ when the clay dosage CQF1 was $0.8 \mathrm{~g} / \mathrm{L}$. The slower reduction in percent removal was found to exist when admixed quarry fines with clay, $39.8 \%$ at the CQF2 dosage of $0.1 \mathrm{~g} / \mathrm{L}$ and it reached up to $86.6 \%$ when its dosage was $0.8 \mathrm{~g} / \mathrm{L}$, a similar trend was observed up to the mix proportion CQF5. The removal percent $68.9 \%$ has shown serious decreasing changes when CQF6 adsorbent was compared to mix proportions. This trend suggests that the equivalency for clay CQF1 was ranging until CQF5. The increase in efficiency could be explained by the increase in negative charge and decrease in electrostatic potential near the solid surface that favors solid-solute interaction. A similar result has been reported when using clay admixed with microsilica for liner material [34]. 


\section{Effect of Metal Concentration}

The initial metal ion concentration varied between 5 and $30 \mathrm{mg} / \mathrm{L}$ in order to obtain optimum concentration. It would be seen from Fig. $3 \mathrm{c}$ that the percentage of metal ions adsorbed increases with increases in initial concentration. The increase in percentage of metal ions adsorbed was attributed to the increase in active sites on the adsorbents evident of the fact that more metal ions are adsorbed [31]. The removal percentage at metal concentration $20 \mathrm{mg} / \mathrm{L}$ was $90.356 \%$ by CQF1 and $72.534 \%$ by CQF6. Moreover, the effect of admixing quarry fines with clay from CQF1 to CQF6 on the adsorption efficiency of various concentrations of copper is shown in Fig. 3c. Close assessment of the figure shows that the adsorption efficiency between CQF1 to CQF4 is almost constant whereas CQF5 and CQF6 move away to a great extent from CQF1. The saturation occurred on the surface where the adsorption takes place and no more metal ions could be adsorbed.

\section{Effects of Time}

Contact time was an important parameter because this factor determines the adsorption kinetics of an adsorbent at a given initial concentration of the adsorbent [31]. The
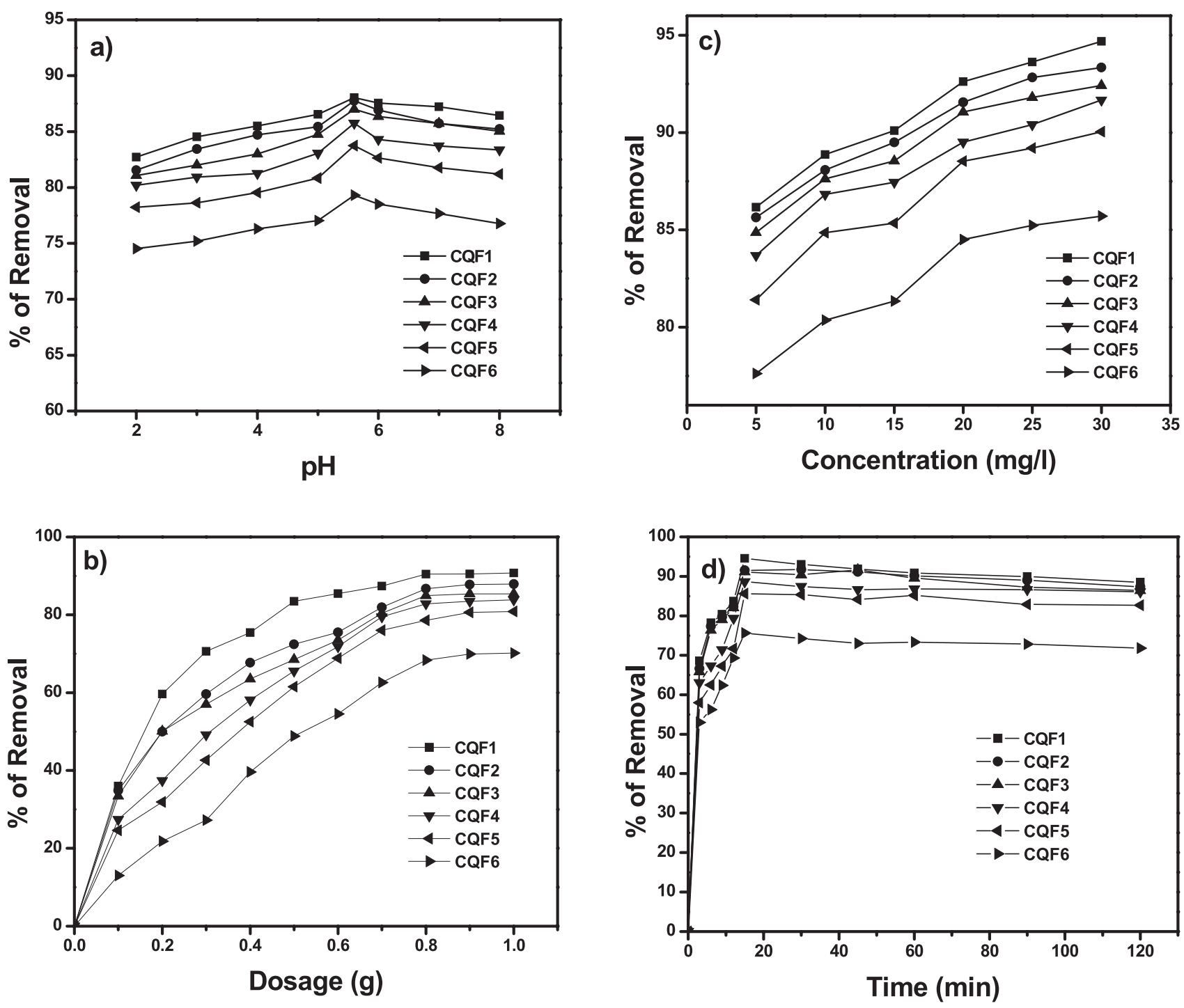

Fig. 3. Adsorption characteristics of clay admixed with quarry fines.

a) Effect of $\mathrm{pH}$ on the removal of copper by clay admixed with quarry fines. Initial metal concentrations $20 \mathrm{mg} / \mathrm{L}$, clay dosage $1 \mathrm{~g} / 100 \mathrm{~mL}$, contact time $120 \mathrm{~min}$.

b) Effect of clay dosage on the removal of copper by clay admixed with quarry fines. Initial metal concentrations $20 \mathrm{mg} / \mathrm{L}$, $\mathrm{pH}$ 5.6, contact time $120 \mathrm{~min}$.

c) Effect of metal concentration on the removal of copper by clay admixed with quarry fines. Clay dosage $0.8 \mathrm{~g} / 100 \mathrm{~mL}, \mathrm{pH} 5.6$, contact time $120 \mathrm{~min}$.

d) Effect of contact time on the removal of copper by clay admixed with quarry fines. Initial metal concentration $20 \mathrm{mg} / \mathrm{L}$, clay dosage $0.8 \mathrm{~g} / 100 \mathrm{~mL}$, $\mathrm{pH} 5.6$. 

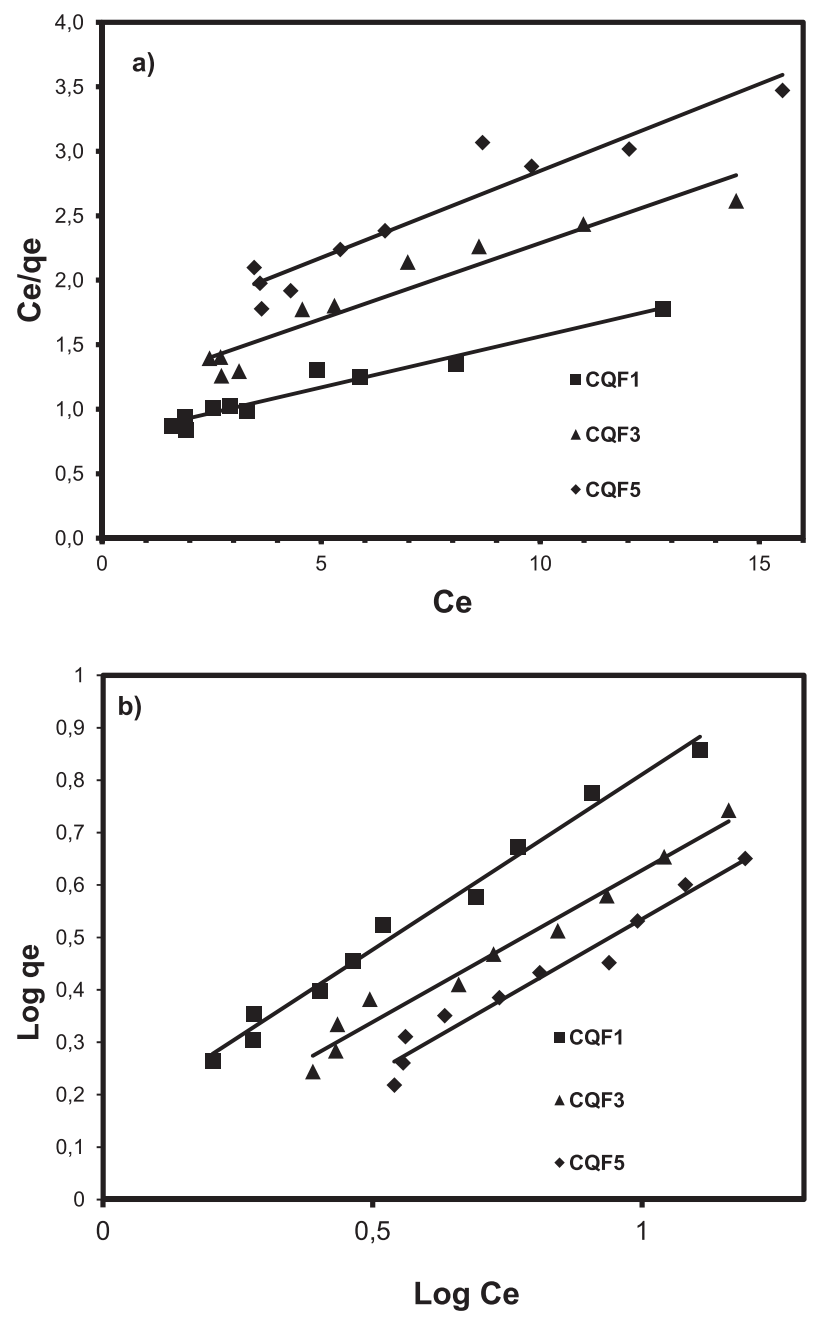

Fig. 4. Adsorption isotherms for copper interactions on clay admixed with quarry fines.

a) Langmuir isotherm b) Freundlich isotherm

study on contact time was carried out to ascertain how extended time would take for the adsorbent to adsorb metal ions at optimum $\mathrm{pH}$ [9]. The influence of mixing time from 3 to $120 \mathrm{~min}$ on $\mathrm{Cu}(\mathrm{II})$ adsorption and removal of various composite mixtures were examined using the optimized parameters from the previous section. The results of this investigation presented in Fig. 3d demonstrate that the chemical equilibrium attained rapidly. As contact time increased from 3 to $15 \mathrm{~min}$, the amount of metal ions adsorbed was found to have increased and at 15 min the amount of removal was found to be a maximum of $94.5 \%$. However, after 15 min the amount of metal ions adsorbed remained approximately constant. The removal of copper was rapid, but it gradually decreased with time until it reached equilibrium. This rapid removal could be elucidated by a significant attraction of the solid support toward copper, as well as with a relatively high drive of this metal in an aqueous solution. The two-phase sorption mechanism with the first swift and quantitatively predominant and the second slower and quantitatively insignificant, has been extensively reported in literature $[18,35]$.

\section{Data Fitting Analysis}

Adsorption isotherms convey valuable information on optimizing the use of adsorbing agents. For instance, a detailed description on the affinity between sorbates and sorbents, as well as bond energy and adsorption capacity, would be inferred from the isotherm equilibrium models of adsorption processes. Freundlich and Langmuir isotherms were the two most commonly employed models for adsorption studies. Langmuir isotherm models the single coating layer on adsorption surface. This model supposes that the adsorption takes place at a specific adsorption surface [36]. Langmuir isotherm and its formulas were described below as:

$$
\mathrm{q}_{\mathrm{e}}=\mathrm{V}_{\mathrm{m}} \mathrm{kC}_{\mathrm{e}} / 1+\mathrm{kC}_{\mathrm{e}}
$$

...where $\mathrm{q}_{e}$ was the amount of adsorbed copper unit adsorbent $(\mathrm{mg} / \mathrm{g}), \mathrm{V}_{\mathrm{m}}$ was the monolayer capacity, $\mathrm{k}$ was the equilibrium constant, and $\mathrm{C}_{\mathrm{e}}$ was the equilibrium concentration of the solution $(\mathrm{mg} / \mathrm{L})$. The above equation can be written in the following linear form:

$$
\mathrm{C}_{\mathrm{e}} / \mathrm{q}_{\mathrm{e}}=1 /\left(\mathrm{kV}_{\mathrm{m}}\right)+\mathrm{C}_{\mathrm{e}} / \mathrm{V}_{\mathrm{m}}
$$

The linear plot between $\mathrm{C}_{\mathrm{e}}$ and $\mathrm{Ce} / \mathrm{q}_{\mathrm{e}}$ of Langmuir adsorption isotherms was used to calculate the adsoption isotherm constants for $\mathrm{CQF} 1, \mathrm{CQF} 3$, and $\mathrm{CQF} 5$ (Fig. 4a). The values of adsorption constants are presented in Table 2. It was observed that the adsorption coefficient $(\mathrm{K})$, maximum adsorption capacity $(\mathrm{mg} / \mathrm{g})$, and correlation coefficient for copper were found to be $0.0943 \mathrm{lmg}^{-1}$ for CQF1, $0.1009 \mathrm{lmg}^{-1}$ forCQF3, and $0.1061 \mathrm{lmg}^{-1}$ for CQF5 and maximum adsorption capacity $13.21(\mathrm{mg} / \mathrm{g})$ for $\mathrm{CQF} 1$, $8.49(\mathrm{mg} / \mathrm{g})$ forCQF3, and $7.42(\mathrm{mg} / \mathrm{g})$ for CQF5, and it

Table 2. Parameters obtained from Langmuir and Freundlich Isotherms for copper adsorption.

\begin{tabular}{|c|c|c|c|c|c|c|c|}
\hline \multirow{2}{*}{$\begin{array}{c}\text { Clay with } \\
\text { Quarry fine } \\
\text { Admixture }\end{array}$} & \multicolumn{3}{|c|}{ Langmuir isotherm constants } & \multicolumn{3}{c|}{ Freundlich isotherm constants } \\
\cline { 2 - 8 } & $\mathrm{K}(1 / \mathrm{mg})$ & $\mathrm{V}_{\mathrm{m}}(\mathrm{mg} / \mathrm{g})$ & $\mathrm{R}^{2}$ & $\mathrm{R}_{\mathrm{L}}$ & $\begin{array}{c}\mathrm{K}_{\mathrm{f}} \\
(\mathrm{l} / \mathrm{mg})\end{array}$ & $\begin{array}{c}\mathrm{n} \\
(\mathrm{mg} / \mathrm{g})\end{array}$ & $\mathrm{R}^{2}$ \\
\hline CQF1 & 0.0943 & 13.21 & 0.9395 & 0.3464 & 1.3864 & 1.4939 & 0.986 \\
\hline CQF3 & 0.1009 & 8.49 & 0.9167 & 0.3204 & 1.1189 & 1.7247 & 0.9744 \\
\hline CQF5 & 0.1061 & 7.42 & 0.9098 & 0.3579 & 1.1389 & 1.6895 & 0.9611 \\
\hline
\end{tabular}


is clearly showing that the adsorption capacity decreased with the increasing quarry fines content. The correlation coefficient was $0.9395,0.9167$, and 0.9098 for CQF1, CQF3, and CQF5, respectively.

The Freundlich isotherm does not have a limit boundary on the maximum capacity of adsorption. Freundlich isotherm was used for modelling the adsorption on heterogeneous surfaces. This isotherm could be explained by the following equation:

$$
\mathrm{q}_{\mathrm{e}}=\mathrm{K}_{\mathrm{f}} \mathrm{C}_{\mathrm{e}}{ }^{1 / \mathrm{n}}
$$

...where $\mathrm{K}_{\mathrm{f}}$ was the Freundlich constant $(\mathrm{mg} / \mathrm{g})$ and $1 / \mathrm{n}$ was the adsorption intensity. The linear form of the above equation can be written as:

$$
\log q_{e}=\log K_{f}+(1 / n) \log C_{e}
$$

The Freundlich adsorption isotherm was a logarithmic plot between $(\mathrm{Ce})$ and $\mathrm{q}_{\mathrm{e}}$ and it was used to caluate the adsoption isotherm constants for CQF1, CQF3, and CQF5 (Fig. 4b). It was observed that the adsorption coefficient $\left(\mathrm{K}_{\mathrm{f}}\right)$ for copper was found to be $1.3864 \mathrm{lmg}^{-1}$ for CQF1, $1.1189 \mathrm{lmg}^{-1}$ for CQF3, and $1.1389 \mathrm{lmg}^{-1}$ for CQF5. An adsorption intensity (n) was found to be $1.4939 \mathrm{mg} / \mathrm{g}$ for CQF1, $1.7247 \mathrm{mg} / \mathrm{g}$ for CQF3, and for CQF5 the ratio had an increased value of $1.6895 \mathrm{mg} / \mathrm{g}$. The correlation co-efficient was $0.986,0.9744$, and 0.9611 for CQF1, CQF3, and CQF5, respectively.

\section{Conclusions}

The results of the present investigation show that clay admixed with quarry fines, as a liner material in landfill, has suitable adsorption capacity with regard to the removal of copper ions from its aqueous solutions. The adsorption process was a function of the adsorbent and adsorbate concentrations, $\mathrm{pH}$, and time of agitation. The effective $\mathrm{pH}$ for copper removal was 5.6. Equilibrium was achieved practically in 15 min with removal of $94.5 \%$. The equilibrium sorption data fits well for Langmuir and Freundlich models but gave a relatively better fit with the Freundlich model. The adsorption isotherms and maximum adsorption factors from batch experiment signify that natural clay admixed with quarry fines has high adsorption capacity on copper heavy metal. The clay replacement level shall be restricted to $20 \%$, as percentage removal of copper decreases adversely beyond this replacement level. The clay admixed with quarry fines was an encouraging aspect from the performance point of copper removal.

\section{Acknowledgements}

The authors thank the authorities of the Technical Education Quality Improvement Programme (TEQIP) for financial assistance in carrying out this study. We also thank the Sophisticated Test and Instrumentation Centre, Cochin University of Science and Technology, Kerala and the Department of Physics, St. Joseph College, Trichy, Tamilnadu, for providing XRD and FTIR results, respectively.

\section{References}

1. SHABIIMAM M.A., ANIL KUMAR DIKSHIT. Treatment of Landfill Leachate using Coagulation $2^{\text {nd }}$ International Conference on Environmental Science and Technology, IPCBEE, IACSIT Press, Singapore,6,119, 2011.

2. ESAKKU S., PALANIVELU K., KURIAN J. Assessment of heavy metals in a municipal solid waste dumpsite. Workshop on Sustainable Landfill Management, Chennai, India, 3-5 December 139, 2003.

3. BELLIR K., LEHOEIKH M.B., MENIAI H., GHERBI N. Study of the retention of heavy metals by natural material used as liners in landfills. Desalination, 185, 111, 2005.

4. VENKATESAN G., SWAMINATHAN G. Microsilica as innovative waste material for used in soil stabilization, liners and concrete, International Journal of Natural and Applied Sciences, 4 (2), 124, 2008.

5. DANIEL, D.E. Geosynthetic Clay Liners Part Two: Hydraulic Properties. Geotechnical Fabrics Report, 14 (5), 22, 1996.

6. AHN W.Y., KANG M.S., YIM S.K., CHOI K.H. Advanced landfill leachate treatment using an integrated membrane process. Desalination, 149, 109, 2002.

7. SEVIL VELI, BILGE ALYUZ. Adsorption of copper and zinc from aqueous solutions by using natural clay. Journal of Hazardous Materials, 149, 226, 2007.

8. OLU-OWOLABIB.I., POPOOLA D.B., UNUABONAH E.I. Removal of $\mathrm{Cu}^{2+}$ and $\mathrm{Cd}^{2+}$ from Aqueous Solution by Bentonite Clay Modified with Binary Mixture of Goethite and Humic Acid. Water, Air and Soil Pollution, 211 (1-4), 459, 2010.

9. EL-NAHHALY., JAMAL SAFI. Adsorption of benzene and naphthalene to modified montmorillonite. Journal of Food, Agriculture and Environment, 3 (2), 295, 2005.

10. GIANNAKOPOULOU F., HAIDOUTI C., CHRONOPOULOU A., GASPARATOS D. Sorption behaviour of cesium on various soils under different $\mathrm{pH}$ levels. Journal of Hazardous Materials, 149, 553, 2007.

11. SUSMITA SEN GUPTA, KRISHNA G. BHATTACHARYYA. Removal of Cd (II) from aqueous solution by kaolinite, montmorillonite and their poly (oxo zirconium) and tetra butyl ammonium derivatives. Journal of Hazardous Materials, 128, 247, 2006.

12. YOUNG DO N., PARK H.I. A Study on Adsorption of Pb, $\mathrm{Cu}, \mathrm{Zn}$ and $\mathrm{Cd}$ Onto Natural Clay. Int. J. Environ. Res. 5 (2), 413, 2011.

13. FATMA AYSUN UGUR, HALIDE SAHAN. Sorption Behaviour of ${ }^{137} \mathrm{Cs}$ on Kaolinite. Ekoloji, 21 (82), 34, 2012.

14. KAMEL M.M., IBRAHM M.A., ISMAEL A.M., ELMOTALEEB M.A., Adsorption of some heavy metal ions from aqueous solutions by using kaolinite clay. Ass. Univ. Bull. Environ 7, 2004.

15. HAJAR MERRIKHPOUR, MOHSEN JALALI. Waste calcite sludge as an adsorbent for the removal of cadmium, copper, lead, and zinc from aqueous solutions. Clean Techn Environ Policy, 14, 845, 2012.

16. HUTAF M., BAKER ADNAN M., MASSADEH, HAMMAD A. YOUNES. Natural Jordanian zeolite: removal 
of heavy metal ions from water samples using column and batch methods. Environ Monit Assess, 157, 319, 2009.

17. HAJAR MERRIKHPOUR, MOHSEN JALALI. Comparative and competitive adsorption of cadmium, copper, nickel, and lead ions by Iranian natural zeolite. Clean Techn Environ Policy, 15, 303, 2013.

18. OZLEM ETCI, NIHAL BEKTAS, M. SALIM ONCEL. Single and binary adsorption of lead and cadmium ions from aqueous solution using the clay mineral beidellite. Environ Earth Sci., 61, 231, 2010.

19. PATRICIA N.M. VASCONCELOS, WELLINGTON S. LIMA, MARTA L.P. SILVA, ANDRE L.F. BRITO, HERVE M. LABORDE, MEIRY G.F. RODRIGUES. Adsorption of Zinc from Aqueous Solutions Using Modified Brazilian Gray Clay. American Journal of Analytical Chemistry, 4, 510, 2013.

20. JOINT COMMITTEE ON POWDER DIFFRACTION STANDARDS. Selected Powder Diffraction Data for Minerals, 1st edition. Data book USA, 1190-1197, 1974.

21. PAUL DJOMGOUE, DANIEL NJOPWOUO. FT-IR Spectroscopy Applied for Surface Clays Characterization. Journal of Surface Engineered Materials and Advanced Technology, 3, 275, 2013.

22. LENKA VACULIKOVA, EVA PLEVOVA. Identification of clay minerals and micas in sedimentary rocks. ActaGeodyn. Geomater, 2 (138), 167, 2005.

23. BARBARA STUART. Infrared spectroscopy fundamental and Applications. Wiley, 2004.

24. VACULIKOVAL., PLEVOVAE., VALLOVAS., KOUTNIK I. Characterization and differentiation of kaolinites from selected czech deposits using infrared spectroscopy and differential thermal analysis. ActaGeodyn. Geomater, 8 (161), 59, 2011.

25. MADEJOVA J., KOMADEL P. Baseline studies of the clay minerals society source clays: infrared methods. Clays and Clay Minerals, 49 (5), 410, 2001.

26. SARALA THAMBAVANI D., KAVITHA B. Mineralogical characterization of river bed soil from tamilnadu by ft-ir, xrd and sem/edax. International Journal of Advanced Research, 2 (2), 656, 2014.
27. PREETI SAGAR NAYAK, SINGH B K. Instrumental characterization of clay by XRF, XRD and FTIR. Bull. Mater. Sci. 30 (3), 235, 2007.

28. GADSEN J.A. Infrared spectra of minerals and related inorganic compounds. London. Butterworths, 1975.

29. BHASKAR J. SAIKIA, GOPALAKRISHNARAO PARTHASARATHY. Fourier Transform Infrared Spectroscopic Characterization of Kaolinite from Assam and Meghalaya, Northeastern India. J. Mod. Phys, 1, 206, 2010.

30. CHAMANCHI M., VAFERIB., ISAAC JALILI. A comparative experimental study of the removal of heavy metals using low cost natural adsorbents and commercial activated carbon. International Journal of Chemical and Environmental Engineering, 3 (1), 55, 2012.

31. PRAKASH N., SUDHA P. N., RENGANATHAN. Copper and cadmium removal from synthetic industrial wastewater using chitosan and nylon 6. Environ Sci. Pollution Res. 19, 2930, 2012.

32. BRTANOVA A., MELICHOVA Z., KOMADEL P. Sorption of $\mathrm{Cu}^{2+}$ from Aqueous Solutions by Slovak Bentonites. Ceramics-Silikaty, 56 (1), 55, 2012.

33. YANHUI LI, BING XIA, QUANSHENG ZHAO, FUQIANG LIU, PAN ZHANG, QIUJU DU, DECHANG WANG, DA LI, ZONGHUA WANG, YANZHI XI. Removal of copper ions from aqueous solution by calcium alginate immobilized kaolin. Journal of Environmental Sciences, 23 (3), 404, 2011.

34. VENKATESAN G., SENTHILNATHAN U., SHAMEELA RAJAM. Cadmium removal from aqueous solutions using hybrid eucalyptus wood based activated carbon: adsorption batch studies. Clean Technologies and Environmental policy, $16(1), 195,2014$.

35. CHUN-RONG WANG, XIN REN, WEN-XIU LI, ZHIFEI HOU, CHAO KE, QI GENG. Adsorption of Zinc and Copper Heavy Metal Ions from Smelting Wastewater Using Modified Lava Particles. Pol. J. Environ. Stud. 22 (6),1863, 2013.

36. PIVATO A., RAGA R. Tests for the evaluation of ammonium attenuation in MSW landfill leachate by adsorption into bentonite in a landfill liner. Waste Management, 26, 123, 2006. 